\title{
Fatal Outcome of COVID-19 in a Newborn
}

\author{
Dragana Savićc ${ }^{1,2} \cdot$ Aleksandra Simović ${ }^{1,2} \cdot$ Dragana Ristić $^{2} \cdot$ Tanja Stojković $^{2} \cdot$ Suzana Živojinović ${ }^{2}$. \\ Tijana Prodanović ${ }^{2} \cdot$ Sladjana Pavlović $^{4} \cdot$ Andjelka Stojković $^{1,2} \cdot$ Zoran Igrutinović $^{1,2} \cdot$ Radiša Pavlović $^{3}$
}

Received: 28 May 2021 / Accepted: 14 June 2021 / Published online: 6 July 2021

(c) Dr. K C Chaudhuri Foundation 2021

To the Editor: Preliminary data during the SARS-CoV-2 pandemic show that the most neonates are reported to be asymptomatic or to have mild symptoms and a good prognosis overall [1].

We report a case of SARS-CoV-2-infected newborn, born on time, with positive rapid antigen (RAG) and polymerase chain reaction (PCR) test at the 3rd hour of life. In asymptomatic mother both tests were also positive. At the 4th hour of life, exacerbation started with hypoxaemia, fever, and signs of nonspecific respiratory distress. After 4 days, the newborn presented with: cyanosis, grunting, tachypnea, tachycardia, and exigency for higher doses oxygen therapy. Blood samples indicated elevated levels of C-reactive protein (CRP), IL6, and D-dimer with no thromboembolic manifestations. We administered oxygen, antimcrobial therapy, dexamethasone, enoxaparin sodium, and pentaglobin. Chest radiography evolved from regular transparency to bilateral ground glass opacities. In the presence of 'cytotoxic storm' and acute respiratory distress syndrome (ARDS), we administered, with parent's approval, tocilizumab $9 \mathrm{mg} / \mathrm{kg}$ divided into two doses in a $12 \mathrm{~h}$ period. At the 9 th day of life, the newborn died.

Pentaglobin early use for 3 consecutive days was shown to slow down the cytokines' hyperactivation in the COVID-19 adult patients [2]. Similarly, we registered clinical improvement and decreased levels of IL6 and CRP.

Dragana Savić

drsavicdragana@gmail.com

1 Faculty of Medical Sciences, Department of Pediatrics, University of Kragujevac, Kragujevac, Serbia

2 Pediatric Clinic, University Clinical Center Kragujevac, Kragujevac, Serbia

3 Faculty of Medical Sciences, Department of Clinical Pharmacy, University of Kragujevac, Kragujevac, Serbia

4 Faculty of Medical Sciences, Center for Molecular Medicine and Stem Cell Research, University of Kragujevac,

Kragujevac, Serbia
As our patient developed ARDS and multiple organ failure in severe COVID-19 cytokine storm, we administered dexamethasone. Immunomodulation approach also includes humanized monoclonal antibodies such as tocilizumab, which has been confirmed to be helpful in treating cytokine storm [3]. Tocilizumab decreased the level of IL6 slowly after $12 \mathrm{~h}$. Given high CRP levels in our case, inflammatory syndrome might be mediated by IL-6.

We reported this case as the first with confirmed SARSCoV-2 infection at the 3rd hour of life, with the aim to urge the need for uniform guidelines for the treatment of this disease.

\section{Declarations}

Conflict of Interest None.

\section{References}

1. Shalish W, Lakshminrusimha S, Manzoni P, Keszler M, Sant'Anna GM. COVID-19 and neonatal respiratory care: current evidence and practical approach. Am J Perinatol. 2020;37:780-91.

2. Mehta P, McAuley DF, Brown M, Sanchez E, Tattersall RS, Manson JJ. HLH Across Speciality Collaboration, UK. COVID-19: consider cytokine storm syndromes and immunosuppression. Lancet. 2020;395:1033-4.

3. Lotfi M, Hamblin MR, Rezaei N. COVID-19: Transmission, prevention, and potential therapeutic opportunities. Clin Chim Acta. 2020;508:254-66.

Publisher's Note Springer Nature remains neutral with regard to jurisdictional claims in published maps and institutional affiliations. 